un triangolino nero accanto alla riga di lemmatizzazione, i casi di assenza della forma standard nel corpus ottocentesco (non ricorre accludere bensí acchiudere, non sussurro ma susurro, non aeronautico ma aereonautico, non elemosiniere ma limosiniere, non epitaffio ma epitafio, ecc.). Sono ancora molte, però, le oscillazioni formali (tra esporre e sporre, esposizione e sposizione, ecc.; forti ancora quelle tra biglietto e viglietto, estate e state, giovane e giovine, grammatica e gramatica, ecc.). Ma il coefficiente di diversità delle forme linguistiche ottocentesche si innalza decisamente quando passiamo ad osservare la morfologia dei verbi, dei pronomi e delle preposizioni articolate: non resta che consultare i lemmi relativi, ad es. dei verbi essere, avere, andare, potere, fare che ci regalano ancora forme come fora, fia, ebbimo, anderà, ponno, potria, ecc., e una miriade di forme di tempi finiti col si o con altri pronomi enclitici (vassi, diessi, evvi, ecc.). Fenomeno questo che ci porterebbe a ripetere ciò che abbiamo detto sulla fortissima conservatività delle strutture sintattiche di questa prosa.

L'opportunissimo ordinamento cronologico dei contesti all'interno di ogni gruppo di forme permetterà di compiere interessanti rilievi sulle tendenze evolutive di questa lingua nell'arco del primo cinquantennio dell'800. Le Liste di frequenza (dapprima alfabetiche, per lemmi e forme, e poi per rango decrescente dei lemmi) offrono un ulteriore ausilio a chi vorrà - ormai potendo - tracciare un profilo della lingua media scritta del primo Ottocento.

Se una storia della nostra lingua va disegnata, come crediamo, in una prospettiva che parta dal presente - cioè dagli esiti che un cosí lungo processo storico ha avuto nella lingua dell'odierna società italiana - non può non apparire subito l'importanza che va attribuita al fenomeno del primo irrompere di una prosa destinata a trattare i piú vari "generi" per un pubblico italiano ormai decisamente allargato, anche se non di massa. Ancora un esempio, molto significativo: come suggerisce la De Stefanis, il precedente stilistico piú diretto della prosa delle moderne cronache sportive si trova nelle cronache teatrali dell'avanzante ' 800 , l'epoca dei primi grandi trionfi della Scala e dei furori suscitati dalla "divina" Malibran.

Sarebbe ingiusto non segnalare anche qui che quest'opera è stata incoraggiata, nel suo lungo cammino, dal consiglio di molti illustri studiosi di storia linguistica italiana (B. Migliorini, G. Nencioni, M. Vitale, G. Lepschy) e di storia del giornalismo (Marino Berengo, Carlo Capra, Franco Della Peruta), e si è giovata dell'ausilio di molti altri studiosi (bibliotecari, ricercatori dell' Accademia della Crusca, ecc.), tutti menzionati dagli autori. Ed inoltre, che alla sua costosissima realizzazione hanno contribuito varie istituzioni canadesi e italiane.

\title{
FRANCESCO SABATINI
}

Università di Roma "La Sapienza"

WILLIAM E. LEPARULO. Maria Montessori scrittrice. Hamilton, Ontario: The Symposium Press, 1984. Pp. 155.

Maria Montessori is perhaps best known for her work, at the turn of this century, in developing sensorial methods of educating mentally or phys- 
ically impaired children. In addition to using visual perception and tactile methods, she stressed spontaneous interaction in an open environment designed to encourage self-motivation and inner discipline. Eventually, her experimental approach was extended to the education of normal children, and so-called "Montessori schools" have become popular on a world-wide basis. The Montessori philosophy is expressed succinctly by Douglas Radcliff-Umstead in the introduction to Leparulo's interesting analysis of Montessori's writings: "the education of the senses had to precede the education of the mind" (p. vi).

The purpose of Leparulo's book is to examine Montessori's writings which he shows to be remarkably unified and coherent despite their heterogeneity. The book is divided into six chapters which focus on the language of Montessori's educational writings. In the first chapter ("Antropologia e impegno civile nella prosa di Maria Montessori," pp. 8-14), Leparulo identifies two components of her style which will provide a framework for the stylistic analysis: gusto and giudizio. The latter refers to the actual scientific subject matter of her writings, and the former to the ways in which she communicates her ideas. Leparulo emphasizes that Montessori's method was revolutionary because it was "interdisciplinary" in the modern sense of the word. The main theme of the second chapter ("Maria Montessori e le correnti di pensiero del tempo," pp. 15-25) is that Montessori's manner of writing parallels remarkably with the development of the novel. In fact, her prose is probably the reason behind the popularity of her method: "la ragione prima del successo straordinario della Montessori nelle scuole e nei circoli educativi d'élite dei paesi piú avanzati del mondo è indubbiamente la sua prosa meravigliosamente poetica, precisa, scientifica e allo stesso tempo popolare" (p. 18). The third ("Analisi della prosa di Maria Montessori," pp. 26-34) and fourth ("Struttura della prosa montessoriana," pp. 35-59) chapters focus on Montessori's prose structure. Basically, Leparulo observes Montessori's style to be scientific in scope yet amazingly accessible and "aesthetic" in structure. In the fifth chapter ("Il lessico," pp. 60-88), Leparulo then examines Montessori's lexical repertoire. Essentially, Leparulo shows how Montessori uses "connotative" - rather than the usual "denotative" devices to enrich her manner of presentation. Finally, in chapter six ("Intrusioni ideologico-affettive," pp. 89-113), Leparulo looks at the overall effect of Montessori's style - a style which reflects her commitment to basic human values even in the scientific domain. The book ends with an extensive bibliography (pp. 129-47) of Montessori's writings and of writings connected with the theme of the book.

To conclude, this book sheds light not only on the thoughts of a distinguished educator and on the ways in which she was able to reach so many people through her personalized style, but also on scientific writing in general. It reminds all those involved in scientific writing that in order to reach a broader audience, the type of language used will be a determining factor.

\section{MARCEL DANESI}

University of Toronto 